\title{
Production of Granulocyte/Macrophage-Colony-stimulating Factor by Human Natural Killer Cells

\author{
Modulation by the p75 Subunit of the Interleukin 2 Receptor and by the CD2 Receptor
}

Lee J. Levitt, ${ }^{*}$ Arnon Nagler,, Frank Lee, ${ }^{\star}$ John Abrams, ${ }^{*}$ Margaret Shatsky, ${ }^{\star}$ and Diana Thompson*

Department of Medicine, *Stanford University Medical Center, Stanford, California 94305; *Veterans Administration Medical Center, Palo Alto, California 94304; and ${ }^{\ddagger}$ DNAX Research Institute of Molecular and Cellular Biology, Palo Alto, California 94304

\begin{abstract}
Resting natural killer (NK) cells express the p75 chain of the IL-2 receptor (IL-2R $\beta$ ) and most NK cells express the CD2 (erythrocyte rosette) receptor. The cell adhesion molecule, LFA-3, is a natural co-ligand for CD2. Tac antigen (IL-2R $\alpha$ ), a p55 IL-2R subunit, can be expressed after NK activation and may play a role in IL-2-induced NK proliferation. Little is known of the molecular mechanisms underlying cytokine production in NK cells. We investigated the roles of IL-2R $\alpha$, IL$2 \mathrm{R} \beta$, and CD2/LFA-3 in the molecular regulation of NK cell granulocyte/macrophage-colony-stimulating factor (GMCSF) production. Enriched populations of peripheral blood NK cells were separated into CD16-positive and CD16-negative fractions by flow cytometry; positively selected cells were $>97 \%$ positive for CD16 (the FcIII receptor for IgG which is present on almost all NK cells), $<1 \%$ positive for the $T$ cell antigen CD3, and did not demonstrate rearrangement of the $T$ cell receptor $\beta$ chain gene by Southern blot. NK cell supernatants were harvested after 3-4 d of incubation with 0-100 U/ml IL-2, or after incubation with anti-CD2 (T11 $)$ MAb and sheep red blood cells (SRBC are a homologue for LFA-3). Parallel cell aliquots were harvested at 3-16 h for transcriptional run-on assays, $S 1$ nuclease assays, and actinomycin D mRNA $t_{1 / 2}$ determinations. IL-2-activated NK supernatants contained large amounts of GM-CSF $(178 \pm 35 \mathrm{pg} / \mathrm{ml})$ by ELISA as did supernatants from CD2-activated NK cells (T11 3 MAb + SRBC: $212 \pm 42) \mathrm{vs}$. $<20 \mathrm{pg} / \mathrm{ml}$ for NK cells incubated alone or with either SRBC or T11 ${ }_{3}$ MAb alone. Sepharose-linked anti-CD3 MAb did not induce GM-CSF release from NK cells. By S1 analysis, both IL-2 and CD2 stimulation markedly augmented GM-CSF mRNA expression but with very different latencies of onset. IL-2R $\beta$ MAb inhibited $>85 \%$ of GM-CSF release from IL-2-activated NK cells and markedly suppressed IL-2induced GM-CSF mRNA expression, whereas IL-2R $\alpha$ MAb even at 2,000-fold molar excess of IL-2 had little effect ( $<10 \%$ ) on either GM-CSF release or mRNA expression. Run-on assays showed that GM-CSF is constitutively transcribed in NK cells and that IL-2 and CD2-activated cells had a three- to fourfold increased rate of GM-CSF transcription compared to nonstimulated cells. The $t_{1 / 2}$ of GM-CSF mRNA in IL-2-acti-
\end{abstract}

Address reprint requests to Dr. Levitt, Room S-161, Hematology Division, Stanford University Medical Center, Stanford, CA 94305.

Received for publication 19 October 1989 and in revised form 23 December 1990.

J. Clin. Invest.

(c) The American Society for Clinical Investigation, Inc. 0021-9738/91/07/0067/09 \$2.00

Volume 88, July 1991, 67-75 vated NK cells was identical to that of unstimulated NK cells (15 min), whereas GM-CSF mRNA $t_{1 / 2}$ in CD2-activated NK cells was increased 2.5 -fold. We conclude that GM-CSF production in NK cells is regulated by both the IL-2R $\beta$ and the CD2 receptor but not by IL-2R $\alpha$, that both transcriptional and posttranscriptional signals act together to modulate the level of GM-CSF mRNA in NK cells, and that the molecular mechanisms underlying NK cell GM-CSF production are dependent in part on differential surface receptor activation. (J. Clin. Invest. 1991. 88:67-75.) Key words: cytotoxicity • granulocyte/ macrophage-colony-stimulating factor $\bullet$ interleukin $2 \cdot$ natural killer cells $\bullet$ receptor $\bullet$ transcription

\section{Introduction}

Interleukin 2 (IL-2) rapidly activates human natural killer $(\mathrm{NK})^{1}$ cells, resulting in augmented cytotoxic activity and proliferation $(1,2)$. The IL-2 receptor (IL-2R) consists of at least two subunits, a p55 (IL-2R $\alpha$ ) glycoprotein and a p75 (IL-2R $\beta$ ) glycoprotein (3). IL-2R $\alpha$ binds IL-2 with low affinity $\left(K_{d} 10^{-8}\right)$ and IL-2R $\beta$ binds IL-2 with intermediate affinity $\left(K_{d} 10^{-9}\right)$. The dimeric receptor consists of both IL-2R $\alpha$ and IL-2R $\beta$ and binds IL-2 with high affinity $\left(K_{d} 10^{-12}\right)(3-5)$. Resting NK cells constitutively express the IL-2R $\beta$ chain of the IL- 2 receptor and do not express the IL-2R $\alpha$ subunit; IL-2R $\alpha$ is expressed after NK activation and plays a role in IL-2-induced NK proliferation (6-8).

Another antigen which is expressed on $>80 \%$ NK cells is the $\mathrm{CD} 2$ (erythrocyte rosette) receptor (9). The $\mathrm{CD} 2$ receptor is also expressed on all $\mathrm{T}$ cells and thymocytes and appears to serve as an antigen-independent pathway of $T$ lymphocyte activation (10). Combinations of anti-CD2 antibodies can stimulate $\mathrm{T}$ cell proliferation (10). The cell surface molecule lymphocyte function-associated antigen-3 (LFA-3) is a natural co-ligand for CD2 and, in combination with a single anti-CD2 antibody, is also capable of enhancing $T$ cell proliferation (11). Cellular activation with a combination of anti-CD2 monoclonal antibodies (MAbs) has recently been shown to enhance cytotoxicity of NK cells against otherwise resistant targets (12).

NK cells have been shown to stimulate both myeloid and erythroid colony growth (13-16). However, in most of these studies the cytokine mediating such stimulatory activity has not been identified and interpretation of results is complicated by heterogeneity of the cell populations assessed. Additionally,

1. Abbreviations used in this paper: BFU-E, erythroid burst-forming units; CFU-GM, granulocyte/macrophage colony-forming units; GMCSF, granulocyte/macrophage colony-stimulating factor; IL-2R, interleukin 2 receptor; IMDM, Iscove's modified Dulbecco's medium; LFA-3, lymphocyte function-associated antigen-3; NAB-T, nonadherent buoyant $T$ cell-depleted marrow mononuclear (cells); NK, natural killer (cells); TNF, tumor necrosis factor. 
cloned human NK cell lines have been reported not to release humoral factors promoting hematopoietic colony growth (17). Cuturi et al. (18) have recently demonstrated that highly purified populations of NK cells can produce granulocyte/macrophage-colony-stimulating factor (GM-CSF), a cytokine with potent hematopoietic stimulatory activity both in vitro and in vivo (18).

Little is known about the molecular mechanisms underlying cytokine expression in NK cells or the potential of NK CD2 or IL-2 surface receptors to modulate cytokine production. We asked whether NK cells are capable of producing GM-CSF and assessed the roles of IL-2R $\alpha$, IL-2R $\beta$, and CD2/LFA- 3 in the molecular regulation of NK cell GM-CSF production.

\section{Methods}

Blood and marrow samples. Peripheral blood and bone marrow aspirates were obtained from normal, healthy adult donors after informed consent. All protocols were approved by the Stanford Medical Committee for the Use of Human Subjects in Research. Blood and marrow samples were diluted in medium and layered over Ficoll-Hypaque gradients (density, $1.077 \mathrm{~g} / \mathrm{cm}^{3}$ ), and mononuclear cells at the interface were collected after washing and centrifugation.

Monoclonal antibodies and cytokines. T lymphocyte MAbs antiLeu-1 (CD5), anti-Leu-2a (CD8), anti-Leu-3a (CD4), and anti-Leu-4 (CD3) were all purchased from Becton, Dickinson \& Co., Mountain View, CA. OKT3 MAb (Ortho Pharmaceuticals, Raritan, NJ) (CD3) is a pan-T cell MAb; in some experiments OKT3 was used after linking to cyanogen Br-Sepharose 4B (Pharmacia Fine Chemicals, Piscataway, NJ) according to published methods (19). Anti-Leu-12 (Becton, Dickinson \& Co.) (CD19) and anti-B1 (Coulter Corp., Hialeah, FL) (CD20) are both pan-B lymphocyte MAbs. Anti-Leu-M3 (Becton, Dickinson $\&$ Co.) (CD14) is a monocyte MAb. Anti-Leu-11 (Becton, Dickinson \& Co.) (CD16) recognizes a 50-70-kD antigen associated with an FcIII receptor for IgG and is present on essentially all peripheral blood NK cells and on neutrophils but is not usually expressed on T cells, B cells, monocytes, or eosinophils (20).

The anti-IL-2R MAbs, Tac-1 (T. Waldmann, National Institutes of Health, Bethesda, MD) and 2A3 (Becton, Dickinson \& Co.) (CD25), react with IL-2R $\alpha$. Both of these anti-IL-2R MAbs directly block IL-2 binding to IL-2R $\alpha$ and cause a consistent dose-dependent inhibition of $T$ cell proliferation induced by anti-CD3 MAb plus IL-2, with virtually complete abrogation at concentrations of $1 \mu \mathrm{g} / \mathrm{ml}(21)$. Tu27 is an IgG MAb that reacts with IL-2R $\beta$ and inhibits IL- 2 binding to that subunit; Tu27 was generously provided by Dr. K. Sugamura, Tohoku University, Sendai, Japan (22). We used cytofluorographic analysis in three independent experiments to assess the ability of TU27 to block biotinylated IL- 2 binding to IL-2R $\beta$ on resting NK cells. TU27 and IL-2 bound separately to $>95 \%$ of purified NK cells; Tu27 MAb suppressed IL-2 binding to $<5 \%$ whereas isotype control MAb had no effect on IL-2 binding.

YTA-1 is an IgG, MAb (Dr. Yodoi, Tohoku University, Kyoto) which also reacts with a p75 subunit of the IL-2R but does not inhibit IL-2 binding (23). Anti-T1 $11_{3}$ MAb recognizes an epitope of the CD2 receptor and was generously provided by E. Reinherz (Dana Farber Cancer Center, Boston, MA) (10). Anti-IL-3 is an IgG, MAb (Genzyme Corp., Boston, MA) which is $>95 \%$ pure by HPLC and demonstrates no reactivity against GM-CSF, IL-2 or IL-4. $500 \mu \mathrm{g}$ of anti-IL-3 completely neutralizes 2,500 U ( $25 \mathrm{ng}$ ) of human IL-3. Anti-GM-CSF is also an IgG 1 MAb (Genzyme Corp.) which is $>95 \%$ pure and demonstrates no reactivity against IL-3 or granulocyte-colony-stimulating factor (G-CSF). $1 \mu \mathrm{g}$ of anti-GM-CSF completely neutralizes $50 \mathrm{U}$ of recombinant GM-CSF. Recombinant IL-2 $\left(4.2 \times 10^{9} \mathrm{U} / \mathrm{g}\right.$ protein) was generously provided by Cetus Corp., Emeryville, CA and was $>98 \%$ pure by HPLC. Recombinant GM-CSF and IL-3 were both purchased from Genzyme Corp.
Isolation of NK cells. Monocytes and B cells were depleted from human peripheral blood mononuclear cells by plastic adherence and passage through nylon wool. The resultant mononuclear cells were fractionated by centrifugation on discontinuous $30 \%$ and $40 \%$ Percol gradients (Pharmacia Fine Chemicals). Low-density cells, enriched for NK cells, were harvested from the gradient interface. Enriched NK cells were then stained with FITC-conjugated anti-Leu-II MAb and separated by fluorescence-activated cell sorting (FACS 440, Becton, Dickinson \& Co.) into CD16-positive and CD16-negative cell fractions (24). CD16-positive cells were $>98 \%$ positive for Leu II (CD16) and $<1 \%$ positive for Leu-4 (CD3) or Leu-5 (CD1). As previously demonstrated, essentially all peripheral blood-derived cytotoxicity against the NK-sensitive K562 cell line was mediated by CD16-positive cells (24). Additionally, Eco RI-digested genomic DNA from CD16-positive cells was assessed by southern blot analysis after hybridization with ${ }^{32} \mathrm{P}$-labeled $\mathrm{C}_{\beta} \mathrm{cDNA}$ derived from the $\mathrm{T}$ cell receptor $\beta$ chain gene. The Eco RI restriction enzyme pattern of CD16-positive cells demonstrated a germline configuration (i.e., two distinct fragments of 10 and $4 \mathrm{~kb}$ ) identical to that of granulocytes whereas CD16-negative cells, which are $>99 \%$ positive for the pan- $T$ antigen $C D 3$, demonstrated an altered pattern of DNA fragments compatible with multiple individual rearrangements within a polyclonal population of $T$ lymphocytes (24). The density ratio of the 10-kb fragment to the 4-kb fragment in CD16-positive cells (1:1) was identical to the ratio in granulocytes.

In some experiments, NK cells were purified by indirect methods utilizing the techniques of solid-phase immunoabsorption and immunomagnetic separation. Enriched NK cells (derived as above from Percoll fractionation) were incubated with $1 \mu \mathrm{g} / \mathrm{ml}$ each of the T cell MAbs anti-CD5, anti-CD4, and anti-CD3, and further depleted of T cells by solid-phase indirect immunoabsorption as previously described (21). Nonbound cells were recovered by differential elution at $4^{\circ} \mathrm{C}$ and subjected to a second immunoabsorption procedure. NK cells were then further purified by immunomagnetic separation: cell suspensions were treated with a combination of anti-CD5, anti-CD4, anti-CD3, anti$\mathrm{CD} 19$, and anti-CD14 MAbs and then incubated at $4^{\circ} \mathrm{C}$ for $40 \mathrm{~min}$ on a rotatory shaker with polystyrene magnetic beads $\left(4 \times 10^{8}\right.$ beads $\left./ \mathrm{ml}\right)$ coated with affinity-purified sheep anti-mouse IgG (Dynabeads M-450, Dynal Inc., Great Neck, NY). NK cells were depleted of immunomagnetic cell rosettes using a magnetic particle concentrator (Dynal MPC 1). Cells were washed and aliquots assessed by flow cytometry: cells were $>95 \%$ positive for Leu-11 $(C D 16)$ and $<1 \%$ positive for Leu-1 (CD5) or Leu-4 (CD3) surface determinants.

Purified nonstimulated NK cells had no demonstrable incorporation of $\left[{ }^{3} \mathrm{H}\right]$ thymidine after a $6-\mathrm{h}$ pulse with $5 \mu \mathrm{Ci} / \mathrm{ml}(2 \mathrm{Ci} / \mathrm{mmol})$ Purified nonstimulated NK cells showed no demonstrable cytotoxicity against the NK-resistant colon carcinoma cell line COLO when assessed in a 4-h ${ }^{51} \mathrm{Cr}$ release assay at $\mathrm{E} / \mathrm{T}$ ratios as high as $15: 1$, whereas NK cells activated for 5-7 d with IL-2 lysed $45-85 \%$ of the tumor targets (E/T ratios of 3:1-15:1). The activation antigens CD25 (IL $2 \mathrm{R} \alpha$ ) and CD71 (transferrin receptor) were not demonstrable on nonstimulated NK cells when assessed by cytofluorography; after IL-2 activation for $6 \mathrm{~d}, 37-52 \%$ of cells expressed CD25 or CD71 after staining with Tac-1 or 5E9 MAbs, respectively.

Cell culture. Purified NK cells were cultured in Iscove's modified Dulbecco's medium (IMDM) containing 15\% FCS for 0.5-4.0 d at a concentration of $10^{6}$ cells $/ \mathrm{ml}$. NK cells were cultured with $0-100 \mathrm{U} / \mathrm{m}$ IL-2 in the presence or absence of anti-IL-2R $\beta$ or isotype-matched control IgG MAbs at a concentration of $10 \mu \mathrm{g} / \mathrm{ml}$. NK cells were also cultured with $10-100 \mathrm{U} / \mathrm{ml} \mathrm{IL-2}(100 \mathrm{pM}$ to $1 \mathrm{nM})$ in the presence of anti-IL-2R $\alpha$ MAb (6.7 nM to $2.0 \mu \mathrm{M}$ ). (Because of the 40 -fold greater affinity of the high-affinity IL-2R for IL-2 than for anti-IL-2R $\alpha$ MAb, it is necessary to use concentrations of anti-IL-2R $\alpha$ MAb in marked excess to prevent IL-2 binding [25]; IL-2R $\alpha$ MAb was thus used at concentrations up to 2,000-fold molar excess of IL-2. Under these conditions IL-2 binds to $<2 \%$ of the available high-affinity IL-2Rs $[7,25]$ ). In some experiments NK cells were cultured with the CD2 MAb anti$\mathrm{T}_{1} 1_{3}(1 \mu \mathrm{g} / \mathrm{ml})$ and/or sheep erythrocytes $\left(10^{7} \mathrm{cells} / \mathrm{ml}\right.$, Microbiological Media, Concord, CA). (Sheep erythrocytes are a homologue for 
LFA-3, which is a natural co-ligand for CD2 [11]). IL-2 and CD2 stimulation produced comparable degrees of NK-mediated cytotoxicity against the lymphoma cell line SU-DHL-4, and resulted in similar $\left[{ }^{3} \mathrm{H}\right]$ thymidine incorporation after $72 \mathrm{~h}$ of stimulation (data not shown). In some experiments, parallel cultures were established from purified (CD16-negative, CD3-positive) $T$ lymphocytes; $T$ cells were cultured with $100 \mathrm{U} / \mathrm{ml}$ IL-2 plus soluble anti-CD3 MAb or with Sepharose-linked anti-CD3 (OKT3) MAb for 0.5-4.0 d before harvest.

Assay for hematopoietic progenitors. Marrow mononuclear cells were depleted of monocytes by sequential polystyrene adherence and subsequently depleted of $T$ cells by sequential solid-phase immunoabsorption as previously described $(26,27)$. Nonadherent buoyant marrow cells depleted of $\mathrm{T}$ lymphocytes (NAB-T) $\left(1.5 \times 10^{5} / \mathrm{ml}\right)$ were cultured in IMDM with $10 \%$ FCS, $0.9 \%$ bovine serum albumin (Armour Pharmaceutical Co., Tarrytown, NY), 1\% L-glutamine, and $1.1 \%$ methylcellulose. Supernatants were added at a final concentration of $15 \%$. Cultures were plated in duplicate in $0.25-\mathrm{ml}$ volumes in microwell plates and human recombinant erythropoietin (Ortho Pharmaceutical) was added at a final concentration of $1 \mathrm{U} / \mathrm{ml}$ on day 3 of culture. After incubation at $37^{\circ} \mathrm{C}$ in $5 \% \mathrm{CO}_{2}$, clonogenic progenitors giving rise to erythroid burst-forming units (BFU-E) and granulocyte/ macrophage colony-forming units (CFU-GM) were enumerated at days 12-14 with an inverted microscope.

GM-CSF ELISA. GM-CSF was detected in culture supernatants by an ELISA immunoassay (Genzyme Corp.). Polystyrene microtiter wells were coated with $100 \mu$ l of mouse anti-human GM-CSF MAb in Tween 20 buffer. Plates were incubated overnight at $4^{\circ} \mathrm{C}$, then washed at $23^{\circ} \mathrm{C}$ and blotted dry. Blocking buffer (Tween 20/BSA, $200 \mu \mathrm{l}$ ) was added to each well and plates were incubated for $2 \mathrm{~h}$ at $37^{\circ} \mathrm{C} .100-\mu$ dilutions of recombinant GM-CSF standard and test samples were then added before incubation for $1 \mathrm{~h}$ at $37^{\circ} \mathrm{C}$. Wells were washed four times with Tween 20 buffer and blotted, and $100 \mu l$ of rabbit anti-human GM-CSF antibody was then added to each well. Plates were incubated again for $1 \mathrm{~h}$ at $37^{\circ} \mathrm{C}$ and blotted before the addition of $100 \mu \mathrm{l}$ of biotin-conjugated goat anti-rabbit antibody to each well. After incubation for $45 \mathrm{~min}$ at $37^{\circ} \mathrm{C}$, plates were washed and blotted before addition of avidin-peroxidase (100 $\mu \mathrm{l}$ per well). After a 40 -min incubation at $37^{\circ} \mathrm{C}, 100 \mu \mathrm{l}$ of $O$-phenylenediamine substrate with peroxide was added. The plates were developed for $5 \mathrm{~min}$ at $23^{\circ} \mathrm{C}$ and the reaction was halted with $100 \mu \mathrm{l}$ of $1 \mathrm{M} \mathrm{H}_{2} \mathrm{SO}_{4}$. Absorbance was measured at 492 $\mathrm{nm}$ with an ELISA reader. Sensitivity of the assay was $20 \mathrm{pg} / \mathrm{ml}$ and no cross-reactivity exists in the assay for IL-3, G-CSF, macrophage-colony-stimulating factor (M-CSF), IL-6, interferon- $\gamma$ (IFN- $\gamma$ ), or tumor necrosis factor-alpha (TNF- $\alpha$ ).

$R N A$ extraction and nuclease S1 protection assay. Total cellular RNA was isolated using a guanidinium thiocyanate-phenol-chloroform extraction procedure (28). RNA samples were quantitated by spectrophotometric analysis at 260 and $280-\mathrm{nm}$. Parallel RNA aliquots were visualized on ethidium bromide-stained $1.2 \%$ agarose-formaldehyde gels to assess integrity of RNA and to verify sample amounts. The 5-prime end-labeled Ncol linearized fragment of GM-CSF cDNA clone 3-8a was hybridized with 10- $\mu \mathrm{g}$ samples of total RNA in $15 \mu \mathrm{l}$ of a solution containing $80 \%$ redistilled formamide, $0.4 \mathrm{M} \mathrm{NaCl}, 1 \mathrm{mM}$ EDTA, and $50 \mathrm{mM}$ PIPES (pH 6.4) at $50^{\circ} \mathrm{C}(29,30)$. Split aliquots of RNA were similarly hybridized with the 5-prime end-labeled Hinfl-linearized fragment of human cytoskeletal $\beta$-actin clone pHF $\beta A-1$ (31). After $6 \mathrm{~h}$ of incubation, $150 \mu \mathrm{l}$ of cold $\mathrm{S} 1$ digestion buffer containing $200 \mathrm{U} / \mathrm{ml}$ S1 nuclease (Boehringer-Mannheim Biochemicals, Indianapolis, IN), $250 \mathrm{mM} \mathrm{NaCl}, 30 \mathrm{mM} \mathrm{NaAc}$, and $1 \mathrm{mM} \mathrm{ZnCl}$ was added to the hybridization mixture and incubated at $37^{\circ} \mathrm{C}$ for $45 \mathrm{~min}$ (30). Samples were transferred to an ice bath for $10 \mathrm{~min}, 10 \mu \mathrm{g}$ of carrier tRNA was added and the S1-resistant hybrids were precipitated by 2 vol of ethanol. Pellets were washed, dried, and resuspended in $10 \mu \mathrm{l} \mathrm{form}$ amide and dye before fractionation on a 5\% polyacrylamide gel containing $7 \mathbf{M}$ urea, with subsequent autoradiography. Autoradiograms were scanned by laser densitometry. Negative controls consisting of labeled cDNA with carrier transfer RNA in the absence of test samples were utilized in each experiment. Labeled cDNA was also hybridized to
$6 \mu \mathrm{g}$ of total cellular RNA derived either from the human T lymphotropic virus-II-infected Mo T cell line (positive control) or from the colon adenocarcinoma cell line A7C (negative control). In some experiments, unstimulated NK cells and cells exposed to either IL-2 or CD2 MAb plus SRBC for $6 \mathrm{~h}$ were cultured with actinomycin $\mathrm{D}(5 \mu \mathrm{g} / \mathrm{ml})$ for 5-120 min before RNA harvest. This amount of actinomycin D suppressed $>95 \%$ of transcription in NK cells as measured by $\left[{ }^{14} \mathrm{C}\right]-$ uridine incorporation.

Nuclear run-on assay. Nuclei were isolated after 3-5 h of stimulation by resuspension in hypotonic buffer $(10 \mathrm{mM}$ Tris [pH 7.4], $10 \mathrm{mM}$ $\mathrm{NaCl}, 5 \mathrm{mM} \mathrm{MgCl}$ ) followed by lysis with $0.5 \%$ Nonidet $\mathrm{P}-40$. The nuclei were harvested by centrifugation, washed twice in hypotonic buffer, suspended in nuclear storage buffer $(50 \mathrm{mM}$ Tris [pH 8.3], 5 $\mathrm{mM} \mathrm{MgCl}, 0.1 \mathrm{mM}$ EDTA, and $40 \%$ glycerol) and stored at $-70^{\circ} \mathrm{C}$ for 1-7 d. Nuclei $\left(40 \times 10^{6}\right)$ were then thawed and incubated for $30 \mathrm{~min}$ at $30^{\circ} \mathrm{C}$ in reaction buffer $(25 \mathrm{mM}$ Tris [pH 8.0]) containing $275 \mu \mathrm{Ci}$ [ $\alpha{ }^{-32}$ P]UTP. RNA was isolated and hybridized for $3 \mathrm{~d}$ to Nytran filters containing $5 \mu \mathrm{g}$ of various dot-blotted immobilized nucleic acids (870bp NcoI GM-CSF coding strand, 404-bp EcoRI $\beta$ actin coding strand, 540-bp EcoRI-HindIII cardiac promotor actin noncoding strand [generously provided by Linda Boxer, Stanford], 1500-bp pBR322 plasmid DNA, yeast tRNA). After hybridization, the blots were washed to a final stringency of $0.1 \times$ SSPE, $0.1 \%$ SDS, then washed for $15 \mathrm{~min}$ at $23^{\circ} \mathrm{C}$ with $\mathrm{RNase}(1 \mu \mathrm{g} / \mathrm{ml})$ in $2 \times \mathrm{SSC}$, and rinsed in $1 \times$ SSPE, $0.1 \%$ SDS.

\section{Results}

GM-CSF production from IL-2- or CD2-activated NK cells. Supernatants from IL-2-activated NK cells contained large amounts of GM-CSF as determined by specific immunoassay (Table I). NK cells did not appear to produce GM-CSF constitutively, inasmuch as supernatants derived from resting NK cells contained little or no detectable GM-CSF. NK cells were also assessed for GM-CSF secretion after stimulation with a CD2 co-ligand (anti-T1 $11_{3} \mathrm{MAb}$ ) and/or SRBC (SRBC are a homologue for LFA-3 which functions as a natural co-ligand for CD2). NK cells activated with both anti-T11 3 MA and SRBC also secreted large amounts of GM-CSF (Table I) although NK cells stimulated with either anti-T1 $11_{3}$ MAb alone or SRBC alone secreted no detectable GM-CSF. Anti-CD3 (OKT3) MAb linked to Sepharose did not induce release of GM-CSF from purified NK cells $(<20 \mathrm{pg} / \mathrm{ml})$ whereas it did

Table I. GM-CSF Production from IL-2-activated or CD2activated NK Cells

\begin{tabular}{lc}
\hline NK activation & GM-CSF \\
\hline & $p g / m l$ \\
None & $<20^{*}$ \\
$10 \mathrm{U} / \mathrm{ml} \mathrm{IL-2}$ & $40 \pm 10$ \\
$100 \mathrm{U} / \mathrm{ml} \mathrm{IL}-2$ & $178 \pm 35$ \\
$\mathrm{~T} 11_{3}$ & $<20$ \\
SRBC & $<20$ \\
T11 $13+$ SRBC & $212 \pm 42$
\end{tabular}

Supernatants were harvested after $4 \mathrm{~d}$ from NK cells ( $>98 \%$ purity by CD16 MAb after selection by flow cytometry) incubated with media alone (None), with 10 or $100 \mathrm{U} / \mathrm{ml} \mathrm{IL}-2$, with anti-CD2 $\mathrm{MAb}\left(T 11_{3}\right)$, with SRBC, or with a combination of anti-CD2 MAb plus SRBC. Supernatants were subsequently assayed by ELISA for GM-CSF activity.

* Mean \pm SEM from four separate experiments. 
induce GM-CSF release ( $125-179 \mathrm{pg} / \mathrm{ml}$ ) from purified peripheral blood $\mathrm{T}$ lymphocytes.

Expression of GM-CSF mRNA was next assessed in nonstimulated and activated NK cells using a nuclease $\mathrm{S} 1$ protection assay (Fig. 1). The protected cDNA which complexed with GM-CSF mRNA is indicated by the arrow at $600 \mathrm{bp}$. Split RNA aliquots were also hybridized to labeled cDNA for $\beta$-actin as a control to ensure that comparable amounts of RNA were in each lane (bands at $450 \mathrm{bp}$ ). Small amounts of GMCSF transcript were detectable in NK cells incubated in media alone and by densitometry remained quantitatively unchanged for $1-15 \mathrm{~h}$ of incubation. No band at $600 \mathrm{bp}$ was seen in the negative control lane (GM-CSF probe hybridized to RNA from a colon adenocarcinoma cell line). The kinetics of GM-CSF expression after either IL-2 or CD2 stimulation were quite different. Augmented expression of GM-CSF mRNA was first observed $6 \mathrm{~h}$ after stimulation of NK cells with $100 \mathrm{U} / \mathrm{ml} \mathrm{IL-2,}$ whereas augmented GM-CSF transcript was noted as early as 1 $h$ after NK activation with anti-T $11_{3}$ MAb plus SRBC. A Sepharose-linked anti-CD3 MAb (OKT3) $(10 \mu \mathrm{g} / \mathrm{ml})$ did not augment NK cell GM-CSF mRNA compared to resting NK cells (not shown).

Effect of IL-2- or CD2-activated NK cells on marrow hematopoietic colony formation. Supernatants derived from either IL-2- or CD2-activated NK cells caused potent stimulation of BFU-E grown from NAB-T marrow (Table II), compared to supernatants from resting NK cells or from NK cells incubated singly with either anti-T $11_{3}$ MAb or SRBC. Supernatants from IL-2- and CD2-activated NK cells also caused potent stimulation of marrow CFU-GM (data not shown).

IL-2 stimulated NK cells to augment erythropoiesis in a dose-dependent manner (Fig. 2). Marked stimulation was observed in the range of $100 \mathrm{pM}$ to $1 \mathrm{nM}(\sim 10-100 \mathrm{U} / \mathrm{ml})$. These IL-2 concentrations are consistent with those concentrations needed to bind the isolated IL-2R $\beta$ subunit of the IL-2 receptor (7).

The addition of anti-GM-CSF MAb to IL-2- or CD2-activated NK cell supernatants suppressed $84-95 \%$ of observed BFU-E stimulation (Table II). In control experiments, identical amounts of anti-GM-CSF MAb inhibited $>96 \%$ of erythroid colony growth induced by $40 \mathrm{pg} / \mathrm{ml}$ of human recombinant GM-CSF yet had virtually no effect on erythroid colony growth induced by human IL-3. Anti-IL-3 MAb had no effect on erythroid stimulation induced by IL-2- or CD2-activated
Table II. Effect of Anti-GM-CSF and Anti-IL-3 MAbs on NK Cell-induced Erythroid Colony Augmentation

\begin{tabular}{|c|c|c|c|c|}
\hline Supernatant & No MAb & $\alpha \mathrm{GM}-\mathrm{CSF}$ & $\alpha \mathrm{IL}-3$ & $\alpha \mathrm{GM}-\mathrm{CSF}+\alpha \mathrm{IL}-3$ \\
\hline & \multicolumn{4}{|c|}{$B F U-E / 1.5 \times 10^{5} B M N A B-T$ cells } \\
\hline NK & $22 \pm 6^{*}$ & - & - & - \\
\hline $\mathrm{NK}+10 \mathrm{U} / \mathrm{ml} \mathrm{IL-2}$ & $116 \pm 21$ & $10 \pm 5$ & $122 \pm 12$ & $14 \pm 5$ \\
\hline $\mathrm{NK}+100 \mathrm{U} / \mathrm{ml} \mathrm{IL-2}$ & $229 \pm 43$ & $12 \pm 4$ & $198 \pm 15$ & $10 \pm 6$ \\
\hline $\mathrm{NK}+\mathrm{T} 11_{3}$ & $16 \pm 5$ & - & - & - \\
\hline $\mathrm{NK}+\mathrm{T} 11_{3}+\mathrm{SRBC}$ & $186 \pm 29$ & $30 \pm 9$ & $174 \pm 18$ & $18 \pm 7$ \\
\hline $\mathrm{rGM}-\mathrm{CSF}(40 \mathrm{pg} / \mathrm{ml})$ & $217 \pm 38$ & $8 \pm 6$ & $227 \pm 15$ & 0 \\
\hline rIL-3 $(50 \mathrm{U} / \mathrm{ml})$ & $156 \pm 24$ & $144 \pm 17$ & $16 \pm 8$ & $2 \pm 1$ \\
\hline
\end{tabular}

Supernatants were harvested after $4 \mathrm{~d}$ from NK cells ( $>98 \%$ positive for CD16) incubated with media alone $(N K)$, with 10 or $100 \mathrm{U} / \mathrm{ml}$ IL-2, with anti-CD2 MAb $\left(T 11_{3}\right)$, or with a combination of anti-CD2 MAb plus SRBC. Anti-GM-CSF MAb ( $\alpha$ GM-CSF, $10 \mu \mathrm{g} / \mathrm{ml})$, antiIL-3 MAb $(\alpha \mathrm{IL}-3,10 \mu \mathrm{g} / \mathrm{ml})$ or a combination of the two MAbs $(\alpha \mathrm{GM}-\mathrm{CSF}+\alpha \mathrm{II}-3)$ were added to the supernatants before the addition of supernatants $(15 \% \mathrm{vol} / \mathrm{vol})$ to marrow NAB-T cultures. Control supernatants containing no MAb were also assessed in marrow cultures. In further control experiments, MAbs were added directly to marrow cultures containing either $40 \mathrm{pg} / \mathrm{ml}$ recombinant GM-CSF or $50 \mathrm{U} / \mathrm{ml}$ recombinant IL-3. After $14 \mathrm{~d}$ of marrow culture, erythroid bursts (BFU-E) were enumerated.

* Mean \pm SEM from two separate experiments.

NK cells nor did it suppress colony growth induced by human recombinant GM-CSF. Anti-IL-3 MAb, however, inhibited $>90 \%$ of erythroid growth induced by human recombinant IL-3 (Table II). The addition of both anti-IL-3 and anti-GMCSF MAbs to NK cell supernatants resulted in marginally greater suppression of erythroid growth than that due to the addition of anti-GM-CSF MAb alone. Erythroid colony growth derived from marrow cultures containing $50 \mathrm{U} / \mathrm{ml}$ recombinant IL-3 was virtually identical in the presence $(144 \pm 17)$ and in the absence $(156 \pm 24)$ of anti-GM-CSF MAb.

Effect of anti-IL-2R $\alpha$ and anti-IL-2R $\beta$ MAbs on GM-CSF production from IL-2-activated NK cells. Preincubation of NK cells with anti-IL-2R $\beta$ MAb (Tu27) markedly suppressed GMCSF release from IL-2-activated NK cells (Table III). An isotype-control $\mathrm{IgG}_{1}$ MAb had no effect on GM-CSF release. Similarly, preincubation with identical amounts of an anti-p75
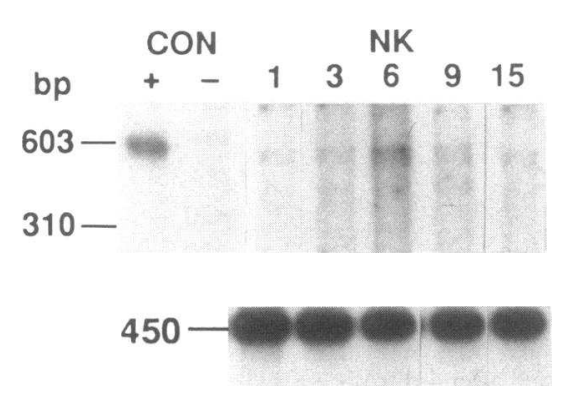
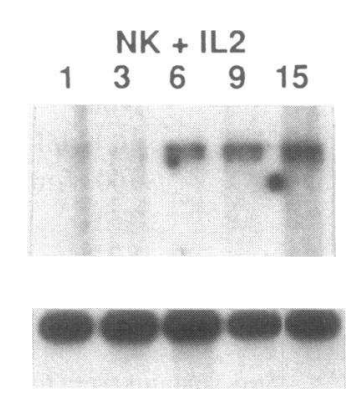
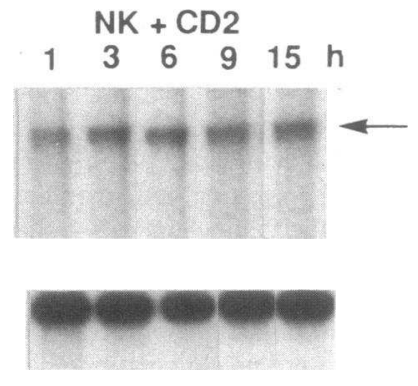

Figure 1. Kinetics of GMCSF mRNA expression in unstimulated and activated NK cells. Purified NK cells were either incubated in media alone $(N K)$, with $100 \mathrm{U} /$ $\mathrm{ml}$ IL-2 $(N K+I L 2)$ or with anti-T $11_{3}$ MAb plus SRBC $(N K+C D 2)$ for $1-15 \mathrm{~h}$ before RNA harvest and analysis by $\mathrm{S} 1$ protection assay. The protected GM-CSF

cDNA probe which hybridized with GM-CSF mRNA is indicated by the arrow at 600 base pairs (bp). Split RNA aliquots were also hybridized with a probe for human $\beta$-actin (bands at $450 \mathrm{bp}$ ). The positive control $(+C O N)$ consisted of GM-CSF cDNA probe plus RNA derived from the HTLV-II-infected Mo T cell line. The negative control $(-C O N)$ comprised GM-CSF probe plus RNA from a colon adenocarcinoma line (A7C). Autoradiograms were developed at various exposures and scanned by laser densitometry. Similar results were found in a total of four independent experiments. 


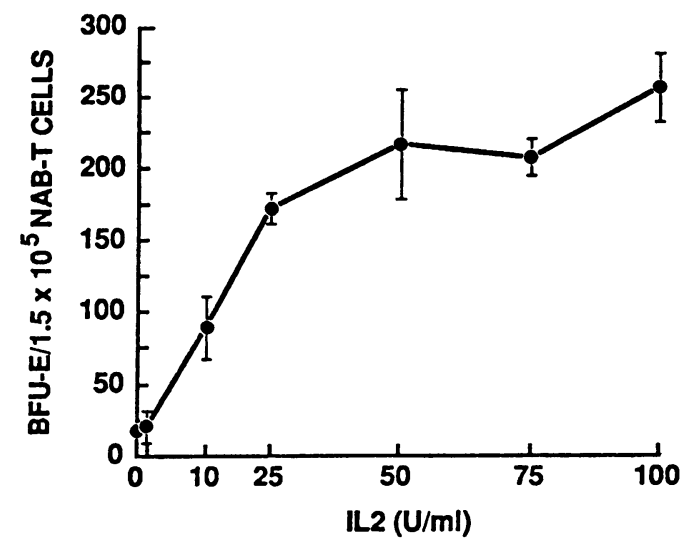

Figure 2. IL-2 stimulates NK cells to augment marrow erythropoiesis in a dose-dependent manner. Supernatants were harvested after $4 \mathrm{~d}$ from NK cells cultured with $0-100 \mathrm{U} / \mathrm{ml} \mathrm{IL}-2$. The supernatants were added ( $15 \% \mathrm{vol} / \mathrm{vol})$ to marrow nonadherent buoyant mononuclear cells depleted of T lymphocytes (NAB-T) and erythroid bursts (BFUE) were enumerated after $12 \mathrm{~d}$ of culture. Results are expressed as means \pm SEM from three separate experiments.

MAb (YTA-1) which fails to block IL-2 binding to the IL-2R also had no effect on GM-CSF release from IL-2-activated NK cells. Anti-IL-2R $\alpha$ MAb (Tac-1, 67 nM), which markedly suppresses IL-2-induced proliferation of $T$ cells bearing the highaffinity IL-2R, had little effect $(<11 \%)$ on GM-CSF release from IL-2-activated NK cells (Table III). Concentrations of anti-IL-2R $\alpha$ MAb, even when used in 2,000-fold molar excess of IL-2, had no additional effect on GM-CSF release. The combination of anti-IL-2R $\beta$ (Tu27) plus anti-IL-2R $\alpha$ MAbs had a very small additional effect on GM-CSF release relative to the suppression observed with anti-IL-2R $\beta$ MAb alone.

Preincubation with anti-IL-2R $\beta$ MAb (Tu27) also markedly suppressed (78-91\%) the ability of IL-2-activated NK

Table III. Effect of Anti-p75 and Anti-p55 IL-2R MAbs on GMCSF production from IL-2-activated NK Cells

\begin{tabular}{lc}
\hline \multicolumn{1}{c}{ NK activation } & GM-CSF \\
\hline & $p g / m l$ \\
None & $<20^{*}$ \\
$\mathrm{NK}+100 \mathrm{U} / \mathrm{ml} \mathrm{IL-2}$ & $285 \pm 41$ \\
$\mathrm{NK}+100 \mathrm{U} / \mathrm{ml} \mathrm{IL}-2+\alpha \mathrm{p} 75 \mathrm{MAb}$ & $41 \pm 11$ \\
$\mathrm{NK}+100 \mathrm{U} / \mathrm{ml} \mathrm{IL}-2+\mathrm{IgG}$ MAb & $245 \pm 33$ \\
$\mathrm{NK}+100 \mathrm{U} / \mathrm{ml} \mathrm{IL}-2+\mathrm{YTA}-1 \mathrm{MAb}$ & $219 \pm 27$ \\
$\mathrm{NK}+100 \mathrm{U} / \mathrm{ml} \mathrm{IL-2}+\alpha \mathrm{p} 55 \mathrm{MAb}$ & $256 \pm 22$ \\
$\mathrm{NK}+100 \mathrm{U} / \mathrm{ml} \mathrm{IL-2}+\alpha \mathrm{p} 55+\alpha \mathrm{p} 75 \mathrm{MAbs}$ & $<20$ \\
\hline
\end{tabular}

Supernatants were harvested after $4 \mathrm{~d}$ from NK cells ( $>98 \%$ positive for CD16) incubated with media alone (None), or with $100 \mathrm{U} / \mathrm{ml}$ IL-2. In some NK cell cultures cells were preincubated with $10 \mu \mathrm{g} / \mathrm{ml}$ anti-p75 (Tu27) MAb ( $\alpha$ p75 MAb), $10 \mu \mathrm{g} / \mathrm{ml}$ of an isotype control $\mathrm{MAb}\left(\mathrm{IgG}_{1}\right), 67 \mathrm{nM}(10 \mu \mathrm{g} / \mathrm{ml})$ of anti-p 55 (Tac-1) MAb ( $\alpha$ p55 MAb) or a combination of both anti-p 55 plus anti-p75 MAbs. In further control experiments, NK cells were preincubated with $10 \mu \mathrm{g} / \mathrm{ml}$ of an anti-p75 MAb (YTA-1) which fails to block IL-2 binding to $\mathrm{p} 75$. Supernatants were subsequently assayed by ELISA for GM-CSF activity.

* Mean \pm SEM from three separate experiments. cells to stimulate marrow BFU-E and CFU-GM, whereas the anti-p75 control MAb (YTA-1) or an anti-IL-2R $\alpha$ MAb (Tac1) had little discernable effect on NK cell-mediated augmentation of colony growth (data not shown).

We next assessed modulation of NK cell GM-CSF mRNA expression by IL-2R $\alpha$ and IL-2R $\beta$ MAbs. RNA was extracted from FACS-purified NK cells and hybridized with labeled GM-CSF cDNA (Fig. 3). The protected band which complexed with GM-CSF mRNA is indicated by the arrow at $600 \mathrm{bp}$; the bands immediately above the arrow represent rehybridized DNA probe. Split RNA aliquots were also hybridized with a cDNA probe for $\beta$-actin and are denoted by the bands at 450 bp. Activation of NK cells with IL-2 (100 U/ml or $1.0 \mathrm{nM})$ again markedly augmented GM-CSF mRNA relative to resting cells. IL-2R $\beta$ MAb (Tu27) (10 $\mu \mathrm{g} / \mathrm{ml})$ strongly suppressed IL-

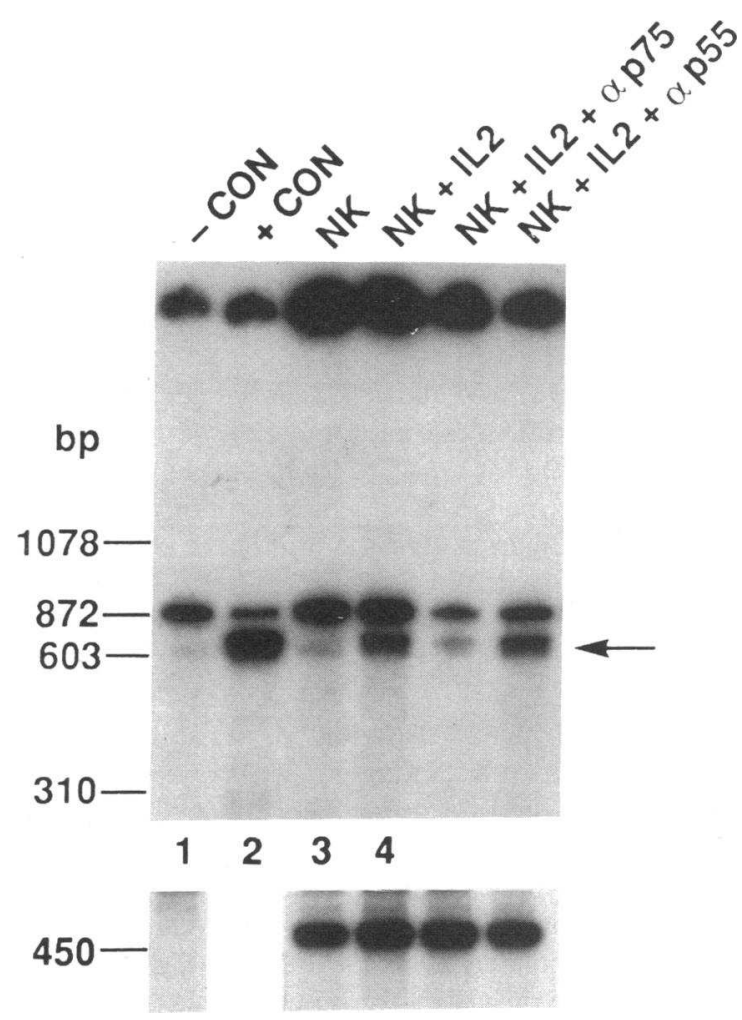

Figure 3. Modulation of NK cell GM-CSF mRNA expression by IL-2 as well as by IL-2R $\alpha$ and IL-2R $\beta$. NK cells were purified from enriched populations of blood mononuclear cells using flow cytometry (sorted cells $>98 \%$ positive for CD16). Cell aliquots were obtained at $12 \mathrm{~h}$ from resting NK cells $(N K)$, from NK cells incubated with $100 \mathrm{U} / \mathrm{ml}$ IL-2 $(N K+I L 2)$, from NK cells incubated with IL-2 plus $10 \mu \mathrm{g} / \mathrm{ml}$ anti-p75 MAb $(N K+I L 2+\alpha p 75)$, or from NK cells incubated with IL-2 plus $670 \mathrm{nM}$ anti-p55 mAb $(N K+I L 2+\alpha p 55)$. RNA was directly extracted from purified NK cells, hybridized with a ${ }^{32} \mathrm{P}$ labeled GM-CSF cDNA probe and GM-CSF mRNA expression assessed by $S 1$ nuclease protection assay. The position of complexed GM-CSF mRNA on the gel is indicated by an arrow (600 bp). The bands immediately above the complexed mRNA represent rehybridized DNA probe. The negative control consisted of labeled cDNA plus carrier RNA without NK cell RNA (-CON). The positive control comprised labeled cDNA plus RNA from a HTLV-II-infected T cell line (Mo cell line) $(+C O N)$. Split RNA aliquots were probed with a cDNA for human $\beta$-actin (bands at $450 \mathrm{bp}$ ). Similar results were seen in two additional experiments. 
2-induced GM-CSF mRNA expression whereas anti-IL-2R $\alpha$ MAb (Tac-1, $670 \mathrm{nM}$ ) had little effect on expression of GMCSF mRNA. Concentrations of anti-IL-2R $\alpha$ MAb, when used in 2,000-fold molar excess of IL-2, had no additional effect on GM-CSF mRNA expression (data not shown). A negative control consisting of the labeled cDNA mixed with carrier RNA alone is also indicated in Fig. $3(-C O N)$ whereas a positive control consisting of labeled cDNA mixed with cellular RNA from a HTLV-II-infected T cell line (Mo) displayed a strong GM-CSF mRNA signal (+CON, Fig. 3). An anti-p75 control MAb (YTA-1) $(10 \mu \mathrm{g} / \mathrm{ml})$ had no discernable effect on GMCSF mRNA expression from IL-2-activated NK cells.

In a separate series of three experiments, RNA was extracted from NK cells purified by negative selection (using solid-phase immunoabsorption and immunomagnetic separation) and GM-CSF mRNA expression again assessed by $\mathrm{S} 1$ protection assay. GM-CSF mRNA was again observed in resting NK cells purified by negative selection; IL-2 $(100 \mathrm{U} / \mathrm{ml})$ strongly augmented GM-CSF mRNA expression (data not shown). Preincubation with anti-IL-2R $\beta$ MAb virtually abrogated IL-2-induced GM-CSF mRNA expression.

Mechanism of augmented GM-CSF expression in stimulated NK cells. Increased levels of GM-CSF mRNA after IL-2 or CD2 activation of NK cells could result from an increased rate of transcription or enhanced stabilization of GM-CSF transcripts which appear to be constitutively expressed in NK cells. To assess possible posttranscriptional regulation of GMCSF transcripts, unstimulated and activated NK cells were cultured with actinomycin $\mathrm{D}(5 \mu \mathrm{g} / \mathrm{ml})$ for 5-120 min. RNA was harvested and examined for GM-CSF mRNA levels by $\mathrm{S} 1$ assay (Fig. 4). The protected GM-CSF bands are indicated in the upper portion of the figure where the numbered lanes correspond to 0-120 min of actinomycin D exposure. Autoradiograms were scanned by laser densitometry and mRNA stability was plotted in the lower portion of the figure. The $t_{1 / 2}$ of GMCSF mRNA in IL-2-activated NK cells was virtually identical to that of unstimulated NK cells (15 min), whereas GM-CSF mRNA $t_{1 / 2}$ in CD2-activated NK cells was increased 2.0-2.5fold in three separate experiments. Neither IL-2 nor CD2 stimulation had any detectable effect on NK cell $\beta$-actin mRNA $t_{1 / 2}$ over $12 \mathrm{~h}$ of actinomycin D exposure; this result is consistent with earlier observations concerning actin $\mathrm{mRNA} t_{1 / 2}$ in stimulated $\mathrm{T}$ cells (32). Calculated GM-CSF mRNA $t_{1 / 2}$ 's were identical when densitometric values were normalized for $\beta$-actin expression.

Transcriptional regulation of NK cell GM-CSF expression was next assessed using an in vitro nuclear run-on assay. In this assay, transcripts were generated by elongation of previously initiated mRNA chains during incubation of isolated nuclei in the presence of $\left[{ }^{32} \mathrm{P}\right]$ UTP. The membrane on the left of Fig. 5 was hybridized to nuclear RNA from CD2-activated NK cells, the center membrane was hybridized to RNA from nonstimulated NK cells, and the membrane on the right was hybridized to RNA from IL-2-activated NK cells. GM-CSF is constitutively transcribed at a low level in nonstimulated NK cells. IL-2 and CD2-activated NK cells demonstrate by densitometry a three- to fourfold increased rate of GM-CSF transcription compared to nonstimulated cells. Similar results were obtained in three independent run-on experiments. Nonstimulated and activated NK cells show equal rates of $\beta$-actin transcription (Fig. 5). No signal was seen after nuclear RNA hybridization to the
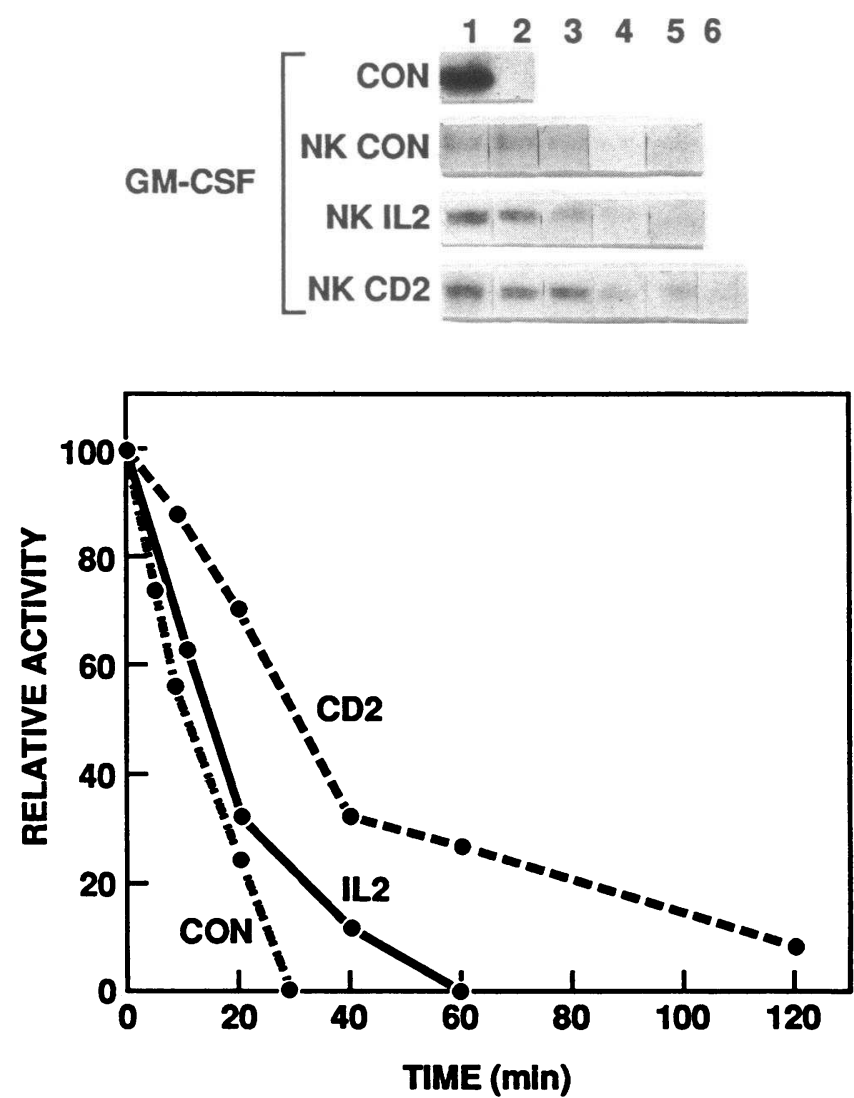

Figure 4. Assessment of GM-CSF mRNA stability in purified NK cells. NK cells were incubated in media alone (NK CON), with 100 $\mathrm{U} / \mathrm{ml} \mathrm{IL-2} \mathrm{(NK} \mathrm{IL2)} \mathrm{or} \mathrm{with} \mathrm{anti-T11}{ }_{3}$ MAb plus SRBC (NK CD2) for $6 \mathrm{~h}$ before the addition of actinomycin $\mathrm{D}(5 \mu \mathrm{g} / \mathrm{ml})$. Cells were cultured in the presence of actinomycin D for 5-120 min before RNA harvest and analysis by $\mathbf{S 1}$ protection assay. The protected GM-CSF bands are indicated in the upper part of the figure. Lane 1 (CON) represents GM-CSF probe hybridized to RNA from the Mo T cell line (+ control) and lane $2(C O N)$ represents GM-CSF probe hybridized to RNA from the adenocarcinoma cell line A7C (-control). Lanes $1-5$ (NK CON) represent GM-CSF probe hybridized to RNA from nonstimulated NK cells cultured with actinomycin $D$ for 0,5 , 10,20 , and $30 \mathrm{~min}$, respectively. Lanes $1-5$ (NK IL2) represent GMCSF probe hybridized to RNA from IL-2-activated NK cells cultured with actinomycin $D$ for $0,10,20,40$, and $60 \mathrm{~min}$, respectively. Lanes 1-6 (NK CD2) represent GM-CSF probe hybridized to RNA from CD2-activated NK cells cultured with actinomycin D for $0,10,20$, 40,60 , and $120 \mathrm{~min}$, respectively. Autoradiograms were scanned by laser densitometry and mRNA stability was plotted as indicated in the lower part of the figure (CON denotes mRNA stability in nonstimulated NK cells; $I L 2$ and $C D 2$ denote mRNA stability in IL-2-stimulated and CD2-stimulated NK cells, respectively). Similar results were seen in three independent experiments. Neither IL-2 nor CD2 activation altered NK cell $\beta$-actin mRNA stability during $12 \mathrm{~h}$ of culture with actinomycin $\mathrm{D}$ (not shown).

negative control immobilized strands (cardiac promotor actin, tRNA and pBR322 plasmid DNA) (Fig. 5). The mean incorporations of $\left.{ }^{32} \mathrm{P}\right] \mathrm{UTP}$ in unstimulated and activated NK cells were nearly equal. In additional, control experiments, the membranes were heated to remove NK cell nuclear RNA and reprobed with labeled nuclear RNA from a C32 melanoma cell line; C32 RNA did not hybridize to the immobilized GM-CSF 


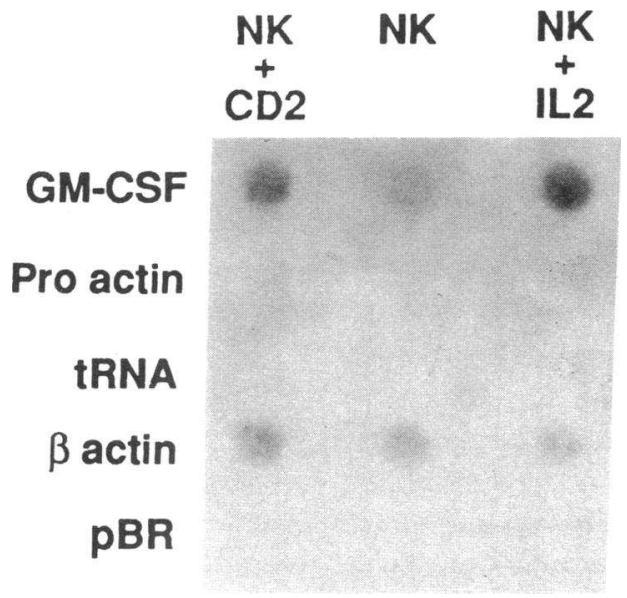

Figure 5. Transcriptional regulation of GM-CSF mRNA in nonstimulated NK cells $(N K)$, NK cells activated with $100 \mathrm{U} / \mathrm{ml} \mathrm{IL-2(NK}$ $+I L 2)$, and in NK cells activated with $\mathrm{T} 11_{3} \mathrm{MAb}$ plus SRBC $(N K$ $+C D 2$ ). Immobilized nucleic acids are indicated on the left of the figure and include the GM-CSF coding strand, cardiac promoter actin (negative control), tRNA (negative control), $\beta$-actin coding strand (positive control) and pBR322 plasmid DNA (negative control). The membrane on the left was hybridized to nuclear RNA from CD2-activated NK cells, the center membrane was hybridized to nuclear RNA from nonstimulated NK cells and the membrane on the right was hybridized to RNA from IL-2-activated NK cells. Similar results were seen in two further experiments.

DNA strand but did hybridize to the $\beta$-actin fragment (not shown).

\section{Discussion}

Our studies indicate that highly purified populations of fresh peripheral blood NK cells produce GM-CSF and that NK cell GM-CSF production is regulated by both IL-2R $\beta$ and CD2/ LFA-3 but not by IL-2R $\alpha$. Supernatants derived from either IL-2- or CD2-activated NK cells cause potent stimulation of hematopoietic colony growth; neutralization studies using specific anti-GM-CSF and anti-IL-3 MAbs indicate that most (84-95\%) of this activity is a consequence of GM-CSF release. These studies also indicate that both transcriptional and posttranscriptional signals act together to modulate the level of GM-CSF mRNA in NK cells, and that the molecular mechanisms underlying NK cell GM-CSF production are dependent in part on differential surface receptor activation.

GM-CSF is one of at least four human colony-stimulating factors capable of augmenting proliferation of hematopoietic progenitor cells both in vitro and in vivo $(33,34)$. It has an apparent molecular mass of $22 \mathrm{kD}$ and is known to be produced by activated $\mathrm{T}$ cells, fibroblasts, and endothelial cells. G-CSF, IL-3, and M-CSF are also variably produced by either monocytes, T cells, or mesenchymal cells (33). Our studies indicate that synthesis of the major colony-stimulating factors may not be restricted to mesenchymal cells, $\mathrm{T}$ lymphocytes, and macrophages.

Production of a number of different cytokines has been attributed to either NK cells or large granular lymphocytes. NK cells have been shown, for example, to produce TNF, IFN$\gamma$, and serine protease-Hanukah factor (35-37). Cuturi et al.
(18) have recently demonstrated that highly purified populations of NK cells express GM-CSF transcripts after stimulation with IL-2 and/or immobilized anti-CD16 MAb. The NK cells utilized in their studies were largely obtained from bulk cultures of peripheral blood mononuclear cells and were incubated for $10 \mathrm{~d}$ with irradiated B-lymphoblastoid cell lines; the vast majority $(83 \%)$ of NK cells purified from these cultures, unlike fresh NK cells, express HLA-DR antigens and $\sim 10 \%$ of their cells also express CD25 (Tac antigen) and thus appear to express activation antigens in the basal state.

The precise in vivo relevance of NK cell cytokine production has not yet been defined. Recent studies using an anti-NK cell MAb to deplete mice of NK cells have suggested that NK cells may serve as a regulator of extramedullary myelopoiesis (38). Three NK cell cytokines (TNF, IFN- $\gamma$, and GM-CSF) are each capable of enhancing peripheral blood phagocytic activity and augmenting microbicidal capacity $(33,39,40)$. NK cells recognize targets in the absence of MHC restriction and represent a probable early line of defense particularly against virusinfected cells and tumor metastases. NK cell release of GMCSF may represent a mechanism for further amplification of the immune response by augmenting the number and function of additional effector cells. NK cells may also represent a unique mediator of CSF release in response to CD16 activation by immune complexes.

It is highly unlikely that contaminating $\mathrm{T}$ lymphocytes were the source of GM-CSF production in our purified populations of NK cells. T cells were not detectable by flow cytometry in purified NK cell populations using an appropriate panel of pan-T MAbs. Secondly, purified NK cells failed to demonstrate rearrangement of the $T$ cell antigen receptor $\beta$ chain gene and by densitometry demonstrated a germline restriction enzyme pattern identical to that of granulocytes, whereas a nongermline configuration compatible with multiple individual gene rearrangements was easily seen in populations of peripheral blood T cells. Thirdly, Sepharose-linked anti-CD3 MAb failed to stimulate GM-CSF release or mRNA production from purified NK cells whereas it readily stimulated lymphokine release from peripheral blood $\mathrm{T}$ cells.

In many of our experiments, enriched NK cells were sorted using flow cytometry into CD16-positive and CD16-negative populations after staining with an anti-CD16 MAb. Ligands for the NK cell CD16 receptor (a low-affinity receptor for the Fc domain of IgG) can induce transcription of cytokine genes and enhance NK cell activation (41). However, ligand binding of the NK cell CD16 receptor by soluble anti-CD16 MAb can not account for the GM-CSF production observed in these studies for at least two reasons. First, NK cell activation and cytokine production after ligand binding to the $\mathrm{CD} 16$ receptor is not generally observed with soluble anti-CD16 antibodies but rather requires either particulate immune complexes or immobilized anti-CD16 antibodies (41). Secondly, similar results were observed in separate experiments when NK cells were purified by negative selection using solid-phase immunoabsorption and immunomagnetic separation.

Relatively few studies have assessed the regulation of cytokine production in human mesenchymal cells or circulating mononuclear cells. In fibroblasts after stimulation with either TNF or 12-O-tetradecanoylphorbol 13-acetate (TPA), both transcriptional and posttranscriptional signals act together to modulate the levels of GM-CSF and G-CSF mRNA (42). IL-1 
also appears to enhance cytokine mRNA stability in fibroblasts, perhaps via the induction of an inhibitor which blocks ribonuclease-induced degradation of cytokine mRNA (43). GM-CSF has been shown to be constitutively transcribed in human fibroblasts and in human $T$ cells immortalized with HTLV-1, but does not appear to be expressed constitutively in primary human $T$ cells $(42,44,45)$. Very little is known about cytokine regulation in human NK cells. Our results indicate that GM-CSF in NK cells is constitutively transcribed at low levels and that both IL-2 and CD2 stimulation markedly enhance NK cell GM-CSF rates of transcription. CD2 but not IL-2 stimulation also appears to modestly enhance GM-CSF mRNA stability; it is likely, however, that transcriptional stimulation rather than enhanced $\mathrm{mRNA}$ stability is largely responsible for CD2-induced augmentation of GM-CSF production in NK cells. It is possible that GM-CSF transcription in nonstimulated NK cells reflects inadvertent cellular activation during the process of purification. However, this possibility seems unlikely for at least three reasons. First, purified NK cells demonstrated no cytotoxic activity against NK-resistant target cells (the colon carcinoma line COLO) even at $\mathrm{E} / \mathrm{T}$ ratios of 15:1 whereas activated NK cells readily kill this cell line. Secondly, purified nonstimulated NK cells did not demonstrate proliferative activity whereas activated NK cells readily incorporate $\left[{ }^{3} \mathrm{H}\right]$ thymidine (7). Thirdly, purified nonstimulated NK cells did not express the activation antigens CD25 (IL-2R $\alpha$ ) or CD71 (transferrin receptor) whereas the majority of activated NK cells express these antigens.

IL-2R $\beta$ is preferentially expressed on resting human peripheral blood NK cells (6-8). It has also been identified in the absence of Tac antigen (IL-2R $\alpha$ ) on the surface of small numbers of resting $T$ cells and some $B$ cells (46). Increasing evidence suggests that IL- $2 R \beta$ is capable of mediating signal transduction $(46,47) .{ }^{125}$ I-IL-2 chemical crosslinking and ${ }^{125}$ I-IL-2 radioreceptor binding assays in the presence and absence of antiTac MAb have indirectly suggested that IL-2 binding to IL$2 \mathrm{R} \beta$ may mediate at least the initial phases of NK cell cytolysis and proliferation as well as the early induction of lymphokineactivated killer (LAK) activity (6-8). The recent production of anti-p75 MAbs which block IL-2 binding to IL-2R $\beta$ now make it possible to more directly assess the function and biologic role of IL-2R $\beta$ in IL-2-mediated cellular activation and cytokine production $(22,48)$. Our studies indicate that anti-IL-2R $\beta$ MAb specifically inhibits GM-CSF release from IL-2-activated NK cells, blocks the ability of IL-2-activated NK cells to augment hematopoietic colony growth and markedly suppresses IL-2-induced GM-CSF mRNA expression. Anti-Tac MAb, which directly blocks IL-2 binding to IL-2R $\alpha$ and inhibits IL2-dependent proliferation of $\mathrm{T}$ lymphocytes, has little effect on NK cell GM-CSF release or mRNA expression, even when used in 2,000-fold molar excess of IL-2. Additionally, the IL-2 concentrations ( $100 \mathrm{pM}$ to $1 \mathrm{nM}$ ) that optimally stimulate NK cell augmentation of erythroid colony growth (Fig. 2) are consistent with those concentrations needed to bind IL-2R $\beta$. Highaffinity IL-2Rs are nearly saturated at $100 \mathrm{pM}$ and the isolated IL-2R $\alpha$ subunit is minimally occupied at $100 \mathrm{pM}$ (7). Taken together, these data strongly suggest that IL-2R $\beta$ is the molecule most directly responsible for IL-2 activation of NK cell GM-CSF production. Together with previous reports, the data suggest that IL- 2 binding to IL-2R $\beta$ may mediate not only NK cell cytolysis and the initial phases of NK cell proliferation but may also play an important role in NK cell cytokine production.

Cellular activation with a combination of anti-CD2 MAbs has been shown to enhance cytotoxicity of NK cell clones against otherwise resistant targets and to enhance the cytolytic function of fresh peripheral blood NK cells $(9,12)$. Similar anti-CD2 MAb combinations can also induce $\mathrm{T}$ cell proliferation; recently, binding of an LFA-3 homologue (SRBC) to T cells has been shown to induce reactivity to otherwise submitogenic concentrations of anti-CD2 MAbs (11). Our studies indicate that SRBC in combination with a single anti-CD2 MAb are capable of enhancing NK cell GM-CSF production even though each ligand alone has a negligible effect on cytokine production. These results suggest that, in addition to IL- $2 R \beta$, CD2 membrane receptors are also capable of modulating NK cell GM-CSF production and that one of the signals required for NK cell activation through the CD2 pathway is provided by the interaction of $\mathrm{CD} 2$ with its naturally occurring co-ligand, i.e., LFA-3. These data also imply that several distinct mechanisms may well be capable of enhancing NK cell cytokine production.

\section{Acknowledgments}

We thank Dr. K. Sugamura for the generous receipt of the Tu27 MAb and Dr. J. Yodoi for providing YTA-1 MAb. Dr. E. Reinherz generously provided anti-T $11_{3}$ MAb. Dr. T. Waldmann kindly provided Tac-1 MAb, and Cetus Corp. generously provided human recombinant IL-2.

This work was supported in part by a grant from the National Institutes of Health (1 R01 HL-35774). Dr. Levitt is the recipient of a Research Career Development Award (K04 HL 02213-01) from the National Institutes of Health.

\section{References}

1. Lanier, L., C. Benike, J. Phillips, and E. Engleman. 1985. Recombinant IL2 enhanced natural killer cell-mediated cytotoxicity in human lymphocyte subpopulations expressing the Leu 7 and Leu 11 antigens. J. Immunol. 134:794-801.

2. Lanier, L., D. Buck, L. Rhodes, A. Ding, E. Evans, C. Barney, and J. Phillips. 1988. Interleukin 2 activation of natural killer cells rapidly induces the expression and phosphorylation of the Leu-23 activation antigen. J. Exp. Med. 167:1572-1585.

3. Teshigawara, K., H. Wang, K. Kato, and K. Smith. 1987. Interleukin 2 high-affinity receptor expression requires two distinct binding proteins. $J$. Exp. Med. 165:223-238.

4. Tsudo, M., R. Kozak, C. Goldman, and T. Waldmann. 1986. Demonstration of a non-Tac peptide that binds interleukin 2: a potential participant in a multichain interleukin 2 receptor complex. Proc. Natl. Acad. Sci. USA. 83:96949698.

5. Robb, R., C. Rusk, J. Yodoi, and W. Greene. 1987. Interleukin 2 binding molecule distinct from the Tac protein: analysis of its role in formation of high-affinity receptors. Proc. Natl. Acad. Sci. USA. 84:2002-2006.

6. Tsudo, M., C. Goldman, K. Bongiovanni, W. Chan, E. Winton, M. Yagita, E. Grimm, and T. Waldmann. 1987. The p75 peptide is the receptor for interleukin 2 expressed on large granular lymphocytes and is responsible for the interleukin 2 activation of these cells. Proc. Natl. Acad. Sci. USA. 84:5394-5398.

7. Siegel, J., M. Sharon, P. Smith, and W. Leonard. 1987. The IL2 receptor $\beta$ chain (p70): role in mediating signals for LAK, NK and proliferative activities. Science (Wash. DC). 238:75-78.

8. Kehrl, J., M. Dukovich, G. Whalen, P. Katz, A. Fauci, and W. Greene. 1988. Novel interleukin 2 receptor appears to mediate IL2-induced activation of natural killer cells. J. Clin. Invest. 81:200-205.

9. Schmidt, R., J. Michon, J. Woronicz, S. Schlossmann, E. Reinherz, and J. Ritz. 1987. Enhancement of natural killer function through activation of the T11 E rosette receptor. J. Clin. Invest. 79:305-308.

10. Meuer, S., R. Hussey, M. Fabbi, D. Fox, O. Acuro, K. Fitzgerald, J. Hodgdon, J. Protentis, S. Schlossman, and E. Reinherz. 1984. An alternative 
pathway of $\mathrm{T}$ cell activation: a functional role for the $50 \mathrm{kD}$ T11 sheep erythrocyte receptor protein. Cell. 36:897-906.

11. Hunig, T., G. Tiefenthaler, K.-H. Meyer zu Buschenfelde, and S. Meuer 1987. Alternative pathway activation of T cells by binding of CD2 to its cell surface ligand. Nature (Lond.). 326:298-301.

12. Siliciano, R., J. Pratt, R. Schmidt, J. Ritz, and E. Reinherz. 1985. Activa tion of cytolytic $\mathrm{T}$ lymphocyte and natural killer cell function through the T1 sheep erythrocyte binding protein. Nature (Lond.). 317:428-430.

13. Pistoia, V., A. Ghio, A. Nocera, A. Leprini, A. Perata, and M. Ferrarini. 1985. Large granular lymphocytes have a promoting activity on human peripheral blood erythroid burst-forming units. Blood 65:464-472.

14. Skettino, S., J. Phillips, L. Lanier, A. Nagler, and P. Greenberg. 1988 Selective generation of erythroid burst promoting activity by recombinant interleukin 2-stimulated human $\mathrm{T}$ lymphocytes and natural killer cells. Blood. 71:907-914

15. Matera, L., D. Santoli, G. Garbarino, L. Pegoraro, G. Bellone, and G. Pagliardi. 1986. Modulation of in vitro myelopoiesis by LGL: different effects on early and late progenitor cells. J. Immunol. 136:1260-1265.

16. Kasahara, T., J. Djeu, S. Dougherty, and L. Oppenheim. 1983. Capacity of human large granular lymphocytes (LGL) to produce multiple lymphokines: interleukin 2, interferon and colony stimulating factor. J. Immunol. 131:23792385 .

17. Herrman, F., R. Schmidt, J. Ritz, and J. Griffin. 1987. In vitro regulation of human hematopoiesis by natural killer cells: analysis at a clonal level. Blood. 69:246-254.

18. Cuturi, M., I. Anegon, F. Sherman, R. Loudon, S. Clark, B. Perussia, and G. Trinchieri. 1989. Production of hematopoietic colony-stimulating factors by human natural killer cells. J. Exp. Med. 169:569-583.

19. Meuer, S., J. Hodgdon, R. Hussey, J. Protentis, S. Schlossman, and E. Reinherz. 1983. Antigen-like effects of monoclonal antibodies directed at receptors on human T cell clones. J. Exp. Med. 158:988-993.

20. Lanier, L., A. Le, J. Phillips, N. Warner, and G. Babcock. 1983. Subpopulations of human natural killer cells defined by expression of the Leu-7 (HNK-1) and Leu-11 (NK-15) antigens. J. Immunol. 131:1789-1796.

21. Burdach, S., and L. Levitt. 1987. Receptor-specific inhibition of bone marrow erythropoiesis by recombinant DNA-derived interleukin 2. Blood. 69:1368-1375.

22. Takeshita, T., Y. Goto, K. Tada, K. Nagata, H. Asao, and K. Sugamura. 1989. Monoclonal antibody defining a molecule identical to the p75 subunit of interleukin 2 receptor. J. Exp. Med. 169:1323-1332.

23. Nakamura, Y., T. Inamoto, K. Sugie, H. Masutani, T. Shindo, Y. Tagaya, K. Ozawa, and J. Yodoi. 1989. Mitogenicity and down-regulation of high affinity interleukin 2 receptor by YTA-1 and YTA-2, monoclonal antibodies that recognize 75-kDa molecules on human large granular lymphocytes. Proc. Natl. Acad. Sci. USA. 86:1318-1322.

24. Nagler, A., L. Lanier, S. Cwirla, and J. Phillips. 1989. Comparative studies of human FCRIII-positive and negative natural killer cells. J. Immunol. 143:3183-3191.

25. Robb, R., W. Greene, and C. Rusk. 1984. Low and high affinity cellular receptors for interleukin 2 . Implications for the level of Tac antigens. J. Exp. Med. 160:1126-1146.

26. Levitt, L., T. Kipps, E. Engleman, and P. Greenberg. 1985. Human bone marrow and peripheral blood $\mathrm{T}$ lymphocyte depletion: efficacy and effects of both T-cells and monocytes on growth of hematopoietic progenitors. Blood. 65:663679.

27. Levitt, L., G. Reyes, D. Moonka, K. Bensch, R. Miller, and E. Engleman. 1988. Human T cell leukemia virus-I-associated T-suppressor cell inhibition of erythropoiesis in a patient with pure red cell aplasia and chronic T-gamma lymphoproliferative disease. J. Clin. Invest. 81:538-548.

28. Chomczynski, P., and N. Sacchi. 1987. Single-step method of RNA isolation by acid guanidinium thiocyanate-phenol-chloroform extraction. Anal. Bio chem. 162:156-159.
29. Lee, F., T. Yokota, T. Otsuka, L. Gemmell, N. Larson, J. Luh, K.-I. Aria, and D. Rennick. 1985. Isolation of cDNA for a human granulocyte-macrophage colony-stimulating factor by functional expression in mammalian cells. Proc. Natl. Acad. Sci. USA. 82:4360-4364.

30. Otsuka, T., A. Miyajima, N. Brown, K. Otsu, J. Abrams, S. Saeland, C. Caux, R. de Wall Malefijt, J. De Vries, P. Meyerson, et al. 1988. Isolation and characterization of an expressible cDNA encoding human IL-3. J. Immunol. 140:2288-2295

31. Gunning, P., P. Ponte, H. Okayama, J. Engel, H. Blau, and L. Kedes 1983. Isolation and characterization of full-length cDNA clones for human $\alpha, \beta$ and $\gamma$ actin RNA's: skeletal but not cytoplasmic actins have an amino-termina cysteine that is subsequently removed. Mol. Cell. Biol. 3:787-795.

32. Young, H., M. Birchenall-Sparks, E. Kovacs, L. Dorman, and F. Ruscetti 1988. Characterization of IL2 and PMA augmentation of expression of transfected human IF gamma genomic DNA. J. Interferon Res. 8:527-538.

33. Clark, S., and R. Kamen. 1987. The human hematopoietic colony-stimulating factors. Science (Wash. DC). 236:1229-1237.

34. Sieff, C. 1987. Hematopoietic growth factors. J. Clin. Invest. 79:15491557.

35. Degliantoni, G., B. Perussia, L. Mangoni, and G. Trinchieri. 1985. Inhibition of bone marrow colony formation by human natural killer cells and by natural killer cell-derived colony-inhibiting activity. J. Exp. Med. 161:11521168.

36. Trinchieri, G., M. Matsumoto-Kobayashi, S. Clark, J. Sheehra, L. London, and B. Perussia. 1984. Response of resting human peripheral blood natura killer cells to interleukin-2. J. Exp. Med. 160:1147-1169.

37. Gershenfeld, H., and I. Weissman. 1986. Cloning of a cDNA for a T cell-specific serine protease from a cytotoxic T lymphocyte. Science (Wash. DC). 232:854-858.

38. Hansson, M., M. Petersson, C. Koo, S. Wigzell, and R. Kiessling. 1988. In vivo function of natural killer cells as regulators of myeloid precursor cells in the spleen. Eur. J. Immunol. 18:485-488.

39. Perussia, B., M. Kobayashi, M. Rossi, I. Anegon, and G. Trinchieri. 1987. Immune interferon enhances functional properties of human granulocytes: role of Fc receptors and effect of lymphotoxin, tumor necrosis factor, and granulocyte-macrophage colony-stimulating factor. J. Immunol. 138:765-774.

40. Klebanoff, S., J. Vadas, M. Harlan, L. Sparks, J. Gamble, J. Agosti, and A Waltersdorph. 1986. Stimulation of neutrophils by tumor necrosis factor. J. Immunol. 136:4220-4225.

41. Anegon, I., M. Cuturi, G. Trinchieri, and B. Perussia. 1988. Interaction of Fc receptor (CD16) ligands induces transcription of interleukin 2 receptor (CD25) and lymphokine genes and expression of their products in human natural killer cells. J. Exp. Med. 167:452-472.

42. Koeffler, H., J. Gasson, and A. Tobler. 1988. Transcriptional and posttranscriptional modulation of myeloid colony stimulating factor expression by TNF and other agents. Mol. Cell. Biol. 8:3432-3438.

43. Bagby, G., T. DeLoughery, M. Heinrich, G. Shaw, M. Brown, A. Freed, and G. Segal. 1990. Molecular determinants of ILl induced mRNA stability in human fibroblasts. Blood. 76:83a (Abstr.).

44. Tobler, A., C. Miller, A. Norman, and H. Koeffler. 1988. 1,25(OH $)_{2} \mathrm{D}_{3}$ modulates expression of a lymphokine (GM-CSF) posttranscriptionally. J. Clin. Invest. 81:1819-1823.

45. Lindsten, T., C. June, J. Ledbetter, G. Stella, and C. Thompson. 1989 Regulation of lymphokine mRNA stability by a surface-mediated $\mathrm{T}$ cell activation pathway. Science (Wash. DC). 244:339-343.

46. Greene, W. 1987. The human interleukin-2 receptor: A molecular and biochemical analysis of structure and function. Clin. Res. 35:439-450.

47. Robb, R., and W. Green. 1987. Internalization of IL-2 is mediated by the beta chain of the high affinity IL2 receptor. J. Exp. Med. 165:1201-1206.

48. Phillips, J., T. Takeshita, K. Sugamura, and L. Lanier. 1989. Activation of natural killer cells via the p75 interleukin 2 receptor. J. Exp. Med. 170:291-296. 